УДК 552.1551 .251

\title{
Order/disorder phase transition in cordierite and its possible relationship to the development of symplectite reaction textures in granulites
}

\author{
C 2007 г. V.L. Vinograd ${ }^{*, * *}$, L.L. Perchuk ${ }^{* *, * * *}$, T.V. Gerya ${ }^{* *, * * * *}$, A. Putnis ${ }^{* * * * *}$, \\ B. Winkler ${ }^{*}$, J.D. Gale ${ }^{* * * * * *}$ \\ * Institute of Geosciences, University of Frankfurt, Senckenberanlage 30, D60050, Frankfurt/Main, Germany \\ ** Institute of Experimental Mineralogy RAN, Tchernogolovka, Moscow District \\ *** Geological faculty, Moscow State University, Vorob'evy Gory, Moscow, 119192 Russia \\ **** Department of Geosciences, Swiss Federal Institute of Technology, ETH, Haldenbachstrasse 44, 8092, \\ Zurich, Switzerland \\ ***** Institute of Mineralogy, University of Münster, Corrensstrasse 24, 48149, Münster, Germany \\ ****** Nanochemistry Research Institute, Curtin University of Technology, P.O. Box U1987, Perth, 6845 WA, \\ Australia
}

Abstract. Based on a consistent set of empirical interatomic potentials, static structure energy calculations of various $\mathrm{Al} / \mathrm{Si}$ configurations in the supercell of $\mathrm{Mg}$-cordierite and Monte Carlo simulations the phase transition between the orthorhombic and hexagonal modifications of cordierite $(\mathrm{Cr} d)$ is predicted at $1623 \mathrm{~K}$. The temperature dependences of the enthalpy, entropy and free energy of the $\mathrm{Al} / \mathrm{Si}$ disorder were calculated using the method of thermodynamic integration. The simulations suggest that the commonly observed crystallization of cordierite in the disordered hexagonal form could be related to a tendency of $\mathrm{Al}$ to occupy $\mathrm{T}_{1}$ site, which is driven by local charge balance. The increase in the $\mathrm{Al}$ fraction in the $\mathrm{T}_{1}$ site over the ratio of 2/3(T1):1/3(T2), that characterizes the ordered state, precludes formation of the domains of the orthorhombic phase. This intrinsic tendency to the crystallization of the metastable hexagonal phase could have significantly postponed the formation of the association of orthorhombic cordierite and orthopyroxene over the association of quartz and garnet in metapelites subjected to ganulite facies metamorphism. The textures of local metasomatic replacement (the formation of $\mathrm{Crd}+\mathrm{Opx}$ or $\mathrm{Spr}+\mathrm{Crd}$ symplectites between the grains of garnet and quartz) indicate the thermodynamic instability of the association of $Q t z+G r t$ at the moment of the metasomatic reaction. This instability could have been caused by the difficulty of equilibrium nucleation of orthorhombic cordierite.

\section{INTRODUCTION}

Thermodynamic effects of mineral transformations depend on the degree of order/disorder of the exchangeable atoms in mineral lattices. Kinetics factors favour the crystallization of mineral phases with high symmetry and chemical disorder (Putnis, 1992). The crystallization of disordered potassium feldspars and dolomites in low-temperature sedimentary rocks are well 
known examples of this phenomenon. Putnis and Holland (1986) have argued that cordierites from contact metamorphic rocks with characteristic sector twins have crystallized initially with the hexagonal, $P 6 / \mathrm{mmc}$, symmetry and later were converted into the orthorhombic, Cccm, form. Using calorimetric data of Carpenter et al., (1983) and ${ }^{29}$ Si NMR measurements of Putnis et al. $(1985,1987)$ Putnis and Holland (1986) could estimate the difference between the free energies of these two structural modifications and show that the higher free energy of the hexagonal phase (indialite) significantly affects the calculated position of cordierite-forming reactions in $P-T$ coordinates. The configurational entropy of cordierite due to the $C \mathrm{ccm} \Leftrightarrow P 6 / \mathrm{mmc}$ transition has been estimated based on the assumption of a linear correlation between the entropy and the fraction of bridging Al-O-Al bonds in the sample (Putnis and Holland, 1986). According to the data of (Putnis et al., 1985, 1987) the fraction of Al-O-Al bonds in synthetic indialite is about one half of the quantity calculated for the case of complete disorder. It was assumed that the configurational entropy of the synthetic indialite is one half the entropy of the ideal mixing between $\mathrm{Al}$ and $\mathrm{Si}(54.53 \mathrm{~J} / \mathrm{K} / \mathrm{mol})$. Since the assumption of the linear correlation might not necessarily hold true, these calculations gave only a rough estimate the magnitude of the reaction shift. A more precise calculation of the free energy difference between the hexagonal and orthorhombic phases requires the development of a quantitative model of order/disorder. The study of Bertram et al. (1990) has outlined the most general approach to similar type problems, which includes calculation of the static lattice energies of various structures with different arrangement of the exchangeable atoms within a supercell of the mineral, calculation of effective pair-wise interaction energies and Monte Carlo simulation of the Boltzmann distribution. The latter simulation should be performed within a supercell which size approaches the thermodynamic limit. Thayaparam et al. (1996) have applied this methodology to Mg-cordierite and compared their results with the spectroscopic measurements of Putnis et al. $(1985,1987)$. It has been shown that computer simulations allow to qualitatively reproduce the ${ }^{29} \mathrm{Si}$ NMR spectrum of the disordered cordierite and to predict the phase transition between the orthorhombic and hexagonal structures at $2000 \mathrm{~K}$ in good agreement with the experimental value 1723 K of Smart and Glasser (1977). However, the results of Thayaparam et al. (1996) have not been subjected to a thermodynamic analysis, which permits calculation of the configurational free energy and entropy as functions of the temperature. Moreover, a detailed analysis of the model of Thayaparam et al. (1996) shows that its predictions are partially at variance with the experiment. Particularly, the model predicts a monotonous equalization of the Al concentrations within the $T_{1}$ and $T_{2}$ sites with the increase in the temperature. However, the spectroscopic data of Putnis et al. $(1985,1987)$ suggest that in the synthetic hexagonal sample the fractions of $\mathrm{Al}$ in $\mathrm{T}_{1}$ and $\mathrm{T}_{2}$ positions are approximately equal to 0.8 and 0.28 , respectively, and thus deviate more strongly from the values $2 / 3(\mathrm{~T} 1): 1 / 3(\mathrm{~T} 2)$, which characterize the ordered phase. This means that 
the fraction of $\mathrm{Al}$ in $\mathrm{T}_{1}$ site within the process of disorder should pass through a maximum. Here we have calculated the enthalpy, entropy and free energy of the Al/Si disorder based on a more accurate model of the $C c c m \Leftrightarrow P 6 / m m c$ transition.

\section{THE METHOD AND THE RESULTS OF CALCULATIONS \\ Development of the interatomic potentials}

The recent progress in computer simulations of the effects of mixing and ordering in aluminosilicates (Thayaparam et al., 1996; Bosenick et al., 2001; Warren et al., 2001; Becker, Pollock, 2002; Vinograd et al., 2006) has been based on models, in which interatomic interactions were parameterized with empirical potentials. The main assumption within this approach is that the interactions between cations and anions are effectively ionic. All ions are attributed with masses and formal charges, while large ions, such as $\mathrm{O}^{2-}$, are often considered polarizeable and described with the help of the shell-model (Dick and Overhauser, 1958). Within this model an anion is represented with a two-particle system composed of the positively charged core and the negatively charged shell. The energy of the core-shell interaction is simulated with a harmonic potential $k_{\mathrm{S}} r^{2}$, where $r$ is the distance between their centres. For an $\mathrm{O}^{2-}$ atom the sum of the charges of core and shell is set equal -2 . The equilibrium structure is achieved due to a balance between long-range Coulombic attraction of the cations and anions and short-range repulsive forces, which imitate the effect of the overlapping of the atomic orbitals. The shortrange interaction is modeled with the Born-Mayer exponential function

$$
E=A \exp (-r / \rho),
$$

where $r$ is the interatomic distance, $A$ and $\rho$ are the adjustable parameters, or with the Buckingham potential, which besides the Born-Mayer term contains the dispersion term $\mathrm{C} / \mathrm{r}^{-6}$, which models dipole-dipole interactions. The covalent contribution to the bonding energy is modeled with a potential, in which the energy of interaction depends on the angle $\phi$, formed by centers of three atoms. The tendency of Si cations to be coordinated by $4 \mathrm{O}^{2-}$ anions is modeled by setting the equilibrium value of the $\mathrm{O}-\mathrm{Si}-\mathrm{O}$ angle, $\phi_{0}$, equal $109.47^{\circ}$, and the energy of the three-atom group is written in the form $k_{\phi}\left(\phi-\phi_{0}\right)^{2}$. The values of $A, \rho, C, k_{\mathrm{s}}, k_{\phi}$ and of the charges of the cores and shells are adjusted in such a way that the equilibrium interatomic distances and the elastic stiffness constants of the virtual crystal were as close as possible to the experimentally known values. These calculations are often performed with the program GULP (Gale, 1997; Gale, Rohl, 2003).

In recent years there have been developed many sets of interatomic potentials which permited modeling of wide class of oxides (Lewis, Catlow, 1985; Bush et al., 1994; Patel et al., 1991; Winkler et al., 1991). The potentials of Winkler et al. (1991) were often used for modeling of aluminosilicates. However, a detailed analysis shows that this set of potentials works well 
only for structures of relatively low density. For densely packed structures, such as stishovite and corundum, the predicted interatomic distances significantly deviate from the experimental ones. Particularly, the distances between highly charged cations, such as $\mathrm{Si}^{4+}$ and $\mathrm{Al}^{3+}$, are often overestimated. Vinograd et al. (2004) have noted that the excessive repulsion between the highly charged cations can be suppressed by decreasing the formal charges of all atoms. Good agreement with the experiment has been achieved by multiplying all charges with the factor 0.85. It is well known that topological charges vary significantly for different ions and for the same ions in different compounds (e.g. Urusov 1997 and references therein). Nevertheless, the introduction of the same averaged multiplier appears useful. The potentials developed based on the reduced charges (table 1) reproduce quite accurately the structural and elastic stiffness constants of cordierite (table 2) and relative energies of different configurations. The fitting procedure was performed along the following scheme. At first, the parameters of $\mathrm{Si}$ (core) - O (shell), $\mathrm{Al}$ (core) - O (shell) and $\mathrm{O}$ (core) - O (shell) potentials were fitted to unit-cell parameters and atomic coordinates of $\alpha$-quartz, coesite, stishovite and corundum. At the next step kyanite, sillimanite and andalusite were included in the fit. The structure data corresponding to the lowest temperatures were selected from the ICSD (National Institute of Standards, Release 2006/2). The stiffness constants were taken from the review of Bass (1995). We observed that the potentials fitted to the data on $\mathrm{SiO}_{2}$ polymorphs and corundum only already describe the structure data and the elastic stiffness tensors of the $\mathrm{Al}_{2} \mathrm{SiO}_{5}$ phases well and require only a fine tuning. The parameters of the $\mathrm{Mg}($ core $)-\mathrm{O}$ (shell) potential were adjusted to the structure and the elastic stiffness data of periclase, $\mathrm{MgSiO}_{3}$-ilmenite, pyrope, $\mathrm{Mg}_{2} \mathrm{SiO}_{4}$-spinel, forsterite and cordierite.

\section{The static lattice energy calculations of the Al/Si configurations in the supercell}

One of the main achievements of the theory of solid solutions in the last decades was the development of the method of cluster expansion (Connolly, Williams, 1983; Sanchez et al., 1984), which permited to write the configuration energy of a disordered structure as a sum of contributions from a hierarchy of clusters. Cluster is a group of exchangeable atoms defined by their relative positions. The simplest example is a pair of atoms. The simplest example of a hierarchy of clusters is the sequence of the first, second, third, etc., pairs of neighbours, where the order of the pair increases with the interatomic distance. Each pair is associated with the interaction energy, $J^{(n)}$, which corresponds to the energy effect of the reaction $\mathrm{AA}+\mathrm{BB}=2 \mathrm{AB}$, where $\mathrm{A}$ and $\mathrm{B}$ are the exchangeable atoms. Therefore, the configurational energy can be written

$$
E_{i} \approx 1 / 2 \sum_{n} z^{(n)} P_{\mathrm{AB}^{(n)}} J^{(n)}+E_{0},
$$


where $P_{\mathrm{AB}}$ is the probability to find a pair of $\mathrm{AB}$ type at the distance $D^{(n)}$ and $E_{0}$ is a constant, which is insensitive to configuration. Since in cordierite, the exchangeable atoms ( $\mathrm{Al} / \mathrm{Si})$ occupy crystallographically different positions $\mathrm{T}_{1}$ и $\mathrm{T}_{2}$, it is convenient to define additional parameter $\mu$ that characterizes the change in energy associated with a move of an $\mathrm{Al}(\mathrm{A})$ atom from $\mathrm{T}_{2}$ to $\mathrm{T}_{1}$. In this case Eqn. 2 contains additional term $P_{\mathrm{A} 1} \mu$, where $P_{\mathrm{A} 1}$ is the probability to find an atom A in $\mathrm{T}_{1}$ site. One assumes that $\mu$ and $J^{(n)}$ are constants and that the dependence of the configurational energy on the arrangement of atoms is defined only by the values of $P_{\mathrm{A} 1}$ and $P_{\mathrm{AB}}{ }^{(n)}$. Therefore, each configuration is characterized with the set of $P_{\mathrm{A} 1}$ and $P_{\mathrm{AB}}{ }^{(n)}$ parameters, and knowing the energies of a sufficient number of different structures allows to write down a system of equations solvable with respect to $\mu, J^{(n)}$ and $E_{0}$. When the number of equations is grater than $n$, the system can be solved with the least squares method. Usually, 20-30 $J^{(n)}$ terms allow sufficiently accurate description of the dependence of the energy on the configuration, while a set of 200-300 structures is sufficient for determining these parameters. In this study we used 250 structures, which were constructed from the ordered cordierite by swapping Al and $\mathrm{Si}$ atoms. For each of the structures we calculated the static lattice energy using the program GULP and determined sets of $P_{1 \mathrm{~A}}$ and $P_{\mathrm{AB}}{ }^{(n)}$ coefficients, which correspond to 30 pairs with the interatomic distances in the range of $3.06-7.84 \AA$. In these calculations we have used $2 \times 2 \times 2$ supercell of $P 6 / m m c$ cordierite ( $a=9.768 \AA, c=9.341 \AA$ ), containing $64 \mathrm{Al}$ and $80 \mathrm{Si}$ atoms. The energy of the completely ordered cordierite was set zero for convenience. The energies of the other structures were considered relative to the fully ordered state. Using the method of least squares we calculated the values of the exchange energies, $\mu$ and $E_{0}$, which correspond to the maximal correlation coefficient $(0.998)$ between the energies of configurations calculated with GULP and those predicted with the cluster expansion (Eqn. 2). Using the exchange energies listed in the table $3, \mu=-46.53$ and $E_{0}=121.316 \mathrm{~kJ} / \mathrm{mol}$ (all values are calculated for 1 mole of the $\mathrm{Al} / \mathrm{Si}$ atoms) and Eqn. (2), one can predict the energy of any configuration with sufficient accuracy avoiding the time consuming energy minimization with GULP. This allows speeding up significantly the Monte Carlo simulations. The negative values of the pair-wise exchange energies (table 3 ) reflect the tendency of $\mathrm{Al}$ and Si to alternate, what in turn permits achieving lower values of the electrostatic energy. The large and negative value of the chemical potential, $\mu$, reflects affinity of $\mathrm{Al}$ atoms for $\mathrm{T}_{1}$ site. This is the consequence of closer proximity of $\mathrm{T}_{1}$ site to the site occupied with $\mathrm{Mg}$. The proximity of $\mathrm{Mg}^{2+}$ atoms alters the charge balance for oxygen atoms, which connect $\mathrm{T}_{1}$ sites together. $\mathrm{A}$ higher concentration of $\mathrm{Al}^{3+}$ in $\mathrm{T}_{1}$ sited restores this balance.

\section{Monte Carlo simulation of disorder}

The rapid decrease of the exchange energies with the increase of the distance between the neighbours (table 3 ) shows that including of more distant pairs in the cluster expansion will lead 
only to a minor increase in the accuracy of the energy calculation. This means also that Eqn. (2) can be applied to supercells of larger size with no significant lost in accuracy. In this study we have used 8x8x6 supercell, consisting of $6912 \mathrm{Al}$ and $\mathrm{Si}$ atoms. Our experience shows that the average energies and other thermodynamic functions calculated for supercells of this size (with the periodic boundary conditions) are practically indistinguishable from properties of infinitely large lattice. The initial distribution of the $\mathrm{Al} / \mathrm{Si}$ in the supercell was that of the fully ordered cordierite. At each simulation step a pair of $\mathrm{Al}$ and $\mathrm{Si}$ atoms was chosen and these atoms were swapped. The new configuration was accepted with the probability $\xi$, the value of which depended on the temperature $T$ and on the energy difference $\Delta E$ between the new and old configurations:

$$
\begin{gathered}
\zeta=1, \Delta E<0 \\
\zeta=\exp (-\Delta E /(k T)), \Delta E \geq 0 .
\end{gathered}
$$

Metropolis et al. (1953) have shown that this acceptance probability (under the condition of a sufficiently large number of steps) leads to the Boltzmann probability distribution of the simulation states. Since the Boltzmann distribution corresponds to the thermodynamic equilibrium of a given system at a given temperature, the thermodynamic functions, such as the energy (enthalpy) of disorder and the parameters of long-range order can be obtained by averaging over a large number of simulated configurations. Such calculations were performed in the interval of 823-2073 K with the step of $50 \mathrm{~K}$. Each state of the system was modeled for $10^{8}$ steps, while only the last $5 * 10^{7}$ steps were used for calculating the averages. The enthalpy of disorder is shown in Fig. 1. The order/disorder transition occurs at about $1623 \mathrm{~K}$. Figure 2 shows the change in the concentrations of $\mathrm{Al}$ in $\mathrm{T}_{1}$ и $\mathrm{T}_{2}$ sites. These concentrations remain essentially constant until the structure remains ordered. When the disordering begins, the fraction of $\mathrm{Al}$ in $\mathrm{T}_{1}$ experiences a rapid increase. With the further increase in the temperature it decreases.

\section{The thermodynamic integration}

Complete thermodynamic description of the process requires the calculation of the free energy and entropy of disorder. However, it is not possible to evaluate these functions from the Monte Carlo results via direct averaging over the simulated configurations. For the calculation of the free energy it is necessary to know how often a configuration with the given energy appears within the sequence of the simulated states. Direct calculation of these frequencies is too difficult. However, Myers et al. (1998) have shown that the free energy can be calculated via the integration of the average enthalpy over the parameter $\lambda$, which characterizes deviation of the equilibrium distribution of atoms from complete chaos:

$$
F=F_{0}+\int_{0}^{\lambda}\langle E\rangle_{\lambda} d \lambda .
$$


$\lambda$-parameter should not be confused with the equilibrium order parameter $Q$, which is a function of the temperature. $\lambda$ helps to model an isothermal transition from the state of thermodynamic equilibrium $(\lambda=1)$ to the state of complete chaos $(\lambda=0)$. The state characterized with $0<\lambda<1$ corresponds to a certain degree of artificially created disorder. To model such a state one needs to simulate the system at a given temperature with the values of the exchange energies and the chemical potential multiplied with the $\lambda$-parameter:

$$
J_{\lambda}^{(n)}=\lambda J^{(n)}, \quad \mu_{\lambda}=\lambda \mu .
$$

Clearly, the case of $\lambda=0$ corresponds to the complete absence of the ordering forces and, consequently, to complete chaos, while the case of $\lambda=1$ corresponds to the equilibrium at the given temperature. The integration constant $F_{0}$ can be conveniently calculated as follows:

$$
F_{0}=-T S_{\text {id }}=9 R T\left(x_{\mathrm{Al}} \ln x_{\mathrm{Al}}+x_{\mathrm{Si}} \ln x_{\mathrm{Si}}\right),
$$

where $x_{\mathrm{Al}}=4 / 9, x_{\mathrm{Si}}=5 / 9$ and $S_{\mathrm{id}}$ is the entropy of ideal mixing. To calculate the integral one splits $\lambda$ in sufficiently narrow intervals. Here the step in $\lambda$ was set equal 0.04 . Therefore, the calculation of the free energy required 25 times longer computing time in comparison with the enthalpy calculation. Figure 3 shows the change in the free energy of the system as the function of temperature. The free energy includes the equilibrium configurational entropy of $\mathrm{Al} / \mathrm{Si}$, which can be easily calculated with the equation

$$
S=(E-F) / T \text {. }
$$

Figure 4 shows the temperature dependence of this function.

\section{Long-range order parameters}

Understanding the origin of the breaks in the functions of the enthalpy and entropy of disorder requires the calculation of the parameters of long-range and short-range order. For cordierite two parameters of long-range order can be defined. In the ordered phase $T_{1}$ and $T_{2}$ sites split in the four subsites $T_{\alpha 1}, T_{\beta 1}, T_{\alpha 2}$ and $T_{\beta 2}$. The probabilities to find $A(A l)$ atom in these subsites are related to the average concentrations of $\mathrm{Al}$ in $\mathrm{T}_{1}$ and $\mathrm{T}_{2}$ sites via the equations:

$$
\begin{aligned}
2 P_{\mathrm{A} \alpha 1}+P_{\mathrm{A} \beta 1} & =3 P_{\mathrm{A} 1} \\
P_{\mathrm{A} \alpha 2}+2 P_{\mathrm{A} \beta 2} & =3 P_{\mathrm{A} 2},
\end{aligned}
$$

where $\alpha$ is the Al-rich site. The order parameters can be defined as follows:

$$
Q_{1}=\frac{P_{\mathrm{A} \alpha 1}-P_{\mathrm{A} \beta 1}}{P_{\mathrm{A} \alpha 1}+P_{\mathrm{A} \beta 1}}, \quad Q_{2}=\frac{P_{\mathrm{A} \alpha 2}-P_{\mathrm{A} \beta 2}}{P_{\mathrm{A} \alpha 2}+P_{\mathrm{A} \beta 2}} .
$$

However, the order parameters cannot be directly calculated from the Monte Carlo simulation results with these equations. The problem is that the long-range order in cordierite can develop in three equally probable ways. Therefore, the crystallographic orientation of the ordering changes 
several times during the simulation, and thus the concentrations of atoms in the subsites cannot be determined using direct averaging over the simulated configurations. At the same time, the probability to find two $\mathrm{Al}$ atoms at a certain distance from each other does not depend on the orientation of long-range order. Moreover, the probability of an Al-Al pair to occupy two sites separated by a large distance depends only on the average concentrations of $\mathrm{Al}$ in $\mathrm{T}_{1}$ and $\mathrm{T}_{2}$ sites and on the degree of long-range order. Short-range order (the correlation between the site occupancies) essentially vanishes at large distances. This fact can be used to calculate the effective long-range order parameter. Note that the probability to find a pair of Al-Al on two distant $\mathrm{T}_{1}$ sites takes the form

$$
P_{\mathrm{A} 1 \mathrm{~A} 1}=1 / 3\left(2 P_{\mathrm{A} \alpha 1} P_{\mathrm{A} \alpha 1}+P_{\mathrm{A} \beta 1} P_{\mathrm{A} \beta 1}\right) .
$$

Similarly, for an Al-Al pair occupying two $\mathrm{T}_{2}$ sites

$$
P_{\mathrm{A} 2 \mathrm{~A} 2}=1 / 3\left(P_{\mathrm{A} \alpha 2} P_{\mathrm{A} \alpha 2}+2 P_{\mathrm{A} \beta 2} P_{\mathrm{A} \beta 2}\right) .
$$

Now using Eqns. (7) and (8) the probabilities to find $\mathrm{Al}$ in the subsites can be written as functions of the average concentrations of $\mathrm{Al}$ in $\mathrm{T}_{1}$ and $\mathrm{T}_{2}$ sites and the long-range order parameters.

$$
\begin{gathered}
P_{\mathrm{A} \alpha 1}=3 P_{\mathrm{A} 1} \frac{1+Q_{1}}{3+Q_{1}}, \quad P_{\mathrm{A} \beta 1}=3 P_{\mathrm{A} 1} \frac{1-Q_{1}}{3+Q_{1}} \\
P_{\mathrm{A} \alpha 2}=3 P_{\mathrm{A} 2} \frac{1+Q_{2}}{3-Q_{2}}, \quad P_{\mathrm{A} \beta 2}=3 P_{\mathrm{A} 2} \frac{1-Q_{2}}{3-Q_{2}}
\end{gathered}
$$

After the substitution of these expressions into Eqns. $(9,10)$ one obtains two quadratic equations, which can be easily solved with respect to $Q_{1}$ and $Q_{2}$. The calculation of these parameters requires only the average $\mathrm{Al}$ concentrations in $\mathrm{T}_{1}$ and $\mathrm{T}_{2}$ and the average probabilities to find AlAl pairs at the distant sites. All these values can be determined via the direct summation over the simulated configurations. In this study the summation was performed for the positions separated by one half of $a$ parameter of the $8 \times 8 \times 6$ supercell. Figure 5 shows the results of these calculations. The both LRO parameters achieve zero values at $1623 \mathrm{~K}$.

\section{Short-range order parameters}

The parameters of short-range order can be also determined from the average probabilities of AlAl pairs. However, in this case, one considers pairs of the nearest neighbours. In cordierite two types of the nearest neighbours can be distinguished: the pairs $T_{1}-T_{2}$ and the pairs $T_{2}-T_{2}$. The average probabilities of the Al-Al events differ significantly for these pairs (Fig. 6). These probabilities can be calculated with the equations

$$
\begin{gathered}
P_{\mathrm{A} 1 \mathrm{~A} 2}=1 / 3\left(2 P_{\mathrm{A} \alpha 1} P_{\mathrm{A} \beta 2}+P_{\mathrm{A} \beta 1} P_{\mathrm{A} \alpha 2}\right)\left(1-\sigma_{12}\right) \\
P_{\mathrm{A} 2 \mathrm{~A} 2}=1 / 3\left(2 P_{\mathrm{A} \alpha 2} P_{\mathrm{A} \beta 2}+P_{\mathrm{A} \beta 2} P_{\mathrm{A} \beta 2}\right)\left(1-\sigma_{22}\right),
\end{gathered}
$$


where $\sigma_{12}$ and $\sigma_{22}$ are the short-range order parameters. These parameters show how much real probabilities of $\mathrm{Al}-\mathrm{Al}$ events differ from those expected from the average $\mathrm{Al}$ concentrations in the subsites and from the assumption of independence of the subsite $\mathrm{Al} / \mathrm{Si}$ distributions. Therefore, the values of the short-range order parameters show how significant is the deviation of this assumption from real situation. Knowing the values of $P_{\mathrm{A} 1 \mathrm{~A} 2}$ and $P_{\mathrm{A} 2 \mathrm{~A} 2}$ from the simulation results and using the long-range order parameters determined as described above, it is possible to calculate these parameters. The results of these calculations (Fig. 7) show that even in the fully disordered indialite there remain strong correlations in the occupancies of the nearest sites. The lower degree of short-range order calculated for $T_{1}-T_{2}$ contacts can be explained by noting that $\mathrm{T}_{1}-\mathrm{T}_{2}$ pairs occur within the 9-member rings of tetrahedra. Rigorous alternation of $\mathrm{Al}$ and $\mathrm{Si}$, consistent with a high degree of short-range order cannot be achieved in rings composed of odd number of sites. The existence of the short-range correlations is also seen in the fact that the configurational entropy of the hexagonal cordierite is significantly below the value computed for the case of complete $\mathrm{Al} / \mathrm{Si}$ randomness (Fig. 4).

\section{DISCUSSION}

\section{The analysis of the model}

The model developed here predicts the complete disappearance of the long-range order in waterfree cordierite at $\sim 1623 \mathrm{~K}$, in good agreement with the experimental value of $1723 \mathrm{~K}$ by Smart and Glasser (1977). Our results for the enthalpy of disorder are in good agreement with the calorimetric measurements of Carpenter et al. (1983). The total effect of ordering of the hexagonal cordierite synthesized at $1473 \mathrm{~K}$ comprises $39 \pm 3 \mathrm{~kJ} / \mathrm{mol}$. This can be compared to the predicted value of $38.19 \mathrm{~kJ} / \mathrm{mol}$ of the enthalpy of disorder at $1623 \mathrm{~K}$. The predicted number of Al-O-Al pairs in the hexagonal phase (Fig. 7) is consistent with the data of Putnis et al. (1985, 1987). It is approximately one half of the value calculated for completely disordered indialite. The predicted value of the configurational entropy $(26.94 \mathrm{~kJ} / \mathrm{mol}$ at $1623 \mathrm{~K})$ is in good agreement with the independent estimate based on the cluster variation method (Putnis, Vinograd, 1999). With this method the value of $27.3 \mathrm{~J} / \mathrm{mol} / \mathrm{K}$ was calculated for the sample of hexagonal cordierite synthesized at $1185^{\circ} \mathrm{C}$.

The most important improvement of the developed model over the previous model of Thayaparam et al. (1996) is the prediction of a significantly higher concentration of $\mathrm{Al}$ in $\mathrm{T}_{1}$ in indialite (Fig. 2). Our estimate of 0.755 approaches the value of 0.8 calculated by Putnis et al. (1985) based on the spectroscopic data. However, the calculations of site occupancies based on

${ }^{29} \mathrm{Si}$ NMR spectra are subjected to large uncertainties. The assumed average uncertainty in measured intensity is about $5 \%$ for the most prominent peaks, while for smaller peaks it can be significantly larger. Therefore, it makes sense to calculate the theoretical spectrum and to directly compare the predicted peak intensities with the experimental ones. The probabilities of 
local groupings $\mathrm{Si}(4 \mathrm{Al}), \mathrm{Si}(3 \mathrm{Al}), \mathrm{Si}(2 \mathrm{Al}), \mathrm{Si}(1 \mathrm{Al})$ and $\mathrm{Si}(0 \mathrm{Al})$ around $\mathrm{Si}\left(\mathrm{T}_{1}\right)$ and $\mathrm{Si}\left(\mathrm{T}_{2}\right)$ atoms, that correspond to the peak intensities of a ${ }^{29} \mathrm{Si} \mathrm{NMR}$ spectrum, can be easily calculated from Monte Carlo simulation results. A comparison of the experimental spectrum of cordierite sample synthesized at $1673 \mathrm{~K}$ (Putnis et al., 1987) with the results of Monte Carlo simulations in the interval of 1573 - $1673 \mathrm{~K}$ (Table 4) shows that the differences between the experimental and theoretical intensities are within 5\%. It follows then that the difference between the concentration of $\mathrm{Al}$ in $\mathrm{T}_{1}$ site predicted here (0.755) and that calculated by Putnis et al. (1985) could be due to the experimental uncertainty. The closest agreement between the experimental and predicted spectra can be obtained by combining the spectra calculated at 1623 and $1573 \mathrm{~K}$. This suggests that the experimental sample was slightly ordered.

Experimental studies show that metastable phases predate the crystallization of ordered cordierite. Schreyer and Schairer (1961) have observed a phase with the structure of $\beta$-quartz that crystallized from the glass of cordierite composition and then rapidly transformed into the hexagonal cordierite (see also Langer, Schreyer, 1969 and Torres, Alarcon, 2004). The orthorhombic phase forms only after a prolonged heating at $1100-1400^{\circ} \mathrm{C}$ (Schreyer, Schairer, 1961; Putnis et al., 1987). In hydrothermal condition only the orthorhombic cordierite is commonly observed (Schreyer, Yoder, 1964; Aranovich, Podlesskii, 1983; Perchuk, Lavrentieva, 1983; Skippen, Gunter, 1996). However, Cho and Fawcett (1986) have noted the presence in the products of their hydrothermal experiments of two phases with different morphology: the slender prismatic grains $(C r d \mathrm{I})$ and the elongated hexagonal prisms (Crd II), where the latter can be certainly identified as the orthorhombic cordierite. It can be also proved that $\mathrm{Crd}$ I have crystallized before $C r d$ II. In longer experiments $C r d$ I-grains have disappeared. Cho and Fawcett (1986) have assumed that $C r d$ I represents the $P 6 / m m c$ phase.

The observations discussed above suggest the possible existence of a barrier that precludes direct nucleation of ordered cordierite. The crystallization begins with the hexagonal precursor, which quickly becomes ordered and promotes the growth of the orthorhombic cordierite. The fastest ordering speed corresponds to hydrothermal conditions. Therefore, indialite has little chance to remain in rocks. The very few described occurrences of indialite refer to exotic rocks which have been subjected to very high temperatures and then rapidly cooled (e.g. Balassone et al., 2004). Kitamura and Hiroi (1982) described an intergrowth of indialite with orthorhombic cordierite. The results of microprobe analysis suggested that the temperature of the order/disorder transition can be greatly reduced in systems with $\mathrm{FeO}$. The $\mathrm{Fe} / \mathrm{Mg}$ ratio is significantly higher in indialite that in the coexisting orthorhombic cordierite. At some cases the existence of indialite can be inferred indirectly. For example, in contact methamorphic rocks from the Prefecture of Kyoto there were described muscovite pseudomorphs over cordierite, Sakura-ishi, which have perfect hexagonal shape with a well defined hexagonal core (Kitamura, 
Yamada, 1987). This shape implies the growth of the cordierite crystal over a precursor with the hexagonal symmetry.

Assuming that the nucleation of indialite occurs in thermodynamic equilibrium with the host rock, the conditions of its crystallization can be calculated based on thermodynamic relations. Since the thermodynamic properties of indialite differ from that of the orthorhombic cordierite, the $P$ - $T$ parameters of crystallization of these phases should be different. Assuming that the configurational enthalpy and entropy of metastable indialite is equal to that of the equilibrium sample at $1623 \mathrm{~K}$ (this temperature corresponds to the lower stability limit of the hexagonal phase), the free energy difference between the two phases can be calculated from the equation:

$$
\Delta G_{\text {hex }}=38190-26.94 T(\mathrm{~kJ} / \mathrm{mol})
$$

The conditions of the first appearance of cordierite in a rock (in case that it nucleates in the disordered form) can be calculated by adding this quantity to the free energy of the equilibrium orthorhombic phase. The free energy difference between the hexagonal and orthorhombic phases is shown in Fig. 3. These calculations agree well with the free energy of the cordierite/indialite transformation $(\sim 6 \mathrm{~kJ} / \mathrm{mol})$ calculated from the change in the slope of the temperature dependence of the $\mathrm{Mg} / \mathrm{Fe}$ distribution coefficient between cordierite and garnet in granulites of Canadian shield (Perchuk, 1977).

\section{Petrological applications}

The observations described above suggest, that at peak metamorphic conditions cordierite could have first crystallized in metapelites as indialite and later transformed into the orthorhombic phase. In $\mathrm{Al}_{2} \mathrm{O}_{3}$-rich granulites cordierite appears in the course of the following reactions (e.g. Korikovski, 1979)

$$
\begin{aligned}
& G r t+Q t z=O p x+C r d \\
& G r t+S i l+Q t z=C r d \\
& O p x+S i l=S p r+C r d+Q t z .
\end{aligned}
$$

Due to the large entropy and volume effects, these reactions could occur not only as a result of a progressive metamorphism, e.g. at constant pressure heating event in the course of the secondary high-temperature metamorphism (Perchuk, 2005; Perchuk et al., 2003, 2006), but also as a result of a retrogression in the course of the decompression related cooling of granulite blocks (Harley, 1989; Perchuk, 1989; Perchuk et al., 2001; Smit et al., 2001).

Putnis and Holland (1986) have shown that due to the free energy difference between the hexagonal and orthorhombic phases of dry cordierite the reaction $O p x+S i l+Q t z=I n d$ shifts to lower pressures with respect to those calculated for the analogous reaction involving the orthorhombic phase. Our calculations using (15) predict a similar decrease in the pressure by 2 kbar at $700^{\circ} \mathrm{C}$ for the reaction $G r t+Q t z=O p x+$ Ind (Fig. 8a). Assuming that the crystallization 
of cordierite always requires a hexagonal precursor, it follows that cordierite crystallizes in the upwelling granulite blocks (Gerya et al., 2000; Perchuk et al., 2001) with a certain delay (at a lower pressure than that calculated for the equilibrium phase). This implies that orthorhombic cordierite, which crystallizes over the hexagonal precursor, is in a strong disequilibrium with the association $G r t+Q t z$. This situation should cause a spontaneous reaction $G r t+Q t z=O p x+$ Crd(ortho).

Do we have a petrographic evidence supporting this supposition? A pair of minerals, which has been moved out of a thermodynamic equilibrium, in the presence of a fluid phase, will react forming a metasomatic column (Korzhinski, 1969). For example, the coronal structure developed between the grains of garnet and quartz (Fig. 8c) in a metapelite from the granulite terrain Limpopo is represented with the following column:

$$
Q t z \mid O p x \text { (rim) } \mid P l+C r d \text { (rim) } \mid O p x+C r d \text { (symplectite) } \mid \operatorname{Grt} \text { (porphyroblast) }
$$

The relict inclusions of quartz can be observed in Mg-rich cores of the garnet grains (Fig. 8c). Reaction (16) between Grt and Qtz begins only when the replacement front reaches the quartz inclusion (e.g. Perchuk et al., 1996). This proves the important role of fluid in the development of the coronal structures. In other samples from the same district the garnet grains are completely replaced with the symplectite (Fig. 9). This supports the assumption that the association of garnet and quartz within the coronal structures is thermodynamically unstable. The model of Ashworth and Chambers (2000) based on arguments of irreversible thermodynamics suggests that the symplectites, which occur within the coronal structures, imply limited diffusion and high rates of the crystal growth. The main conclusion of the model is the inverse relationship between the average modulation period of the symplectite phase composition and the driving force of the reaction, $\Delta G$. This means that symplectite intergrowths are indicators of non-equilibrium crystallization.

Coronal structures are typical for metapelites subjected to granulite facies metamorphism (e.g. Korikovski, 1979; Harley, 1989; Perchuk, 1989; Gerya et al., 2000; Perchuk et al., 2001; Perchuk et al., 1996, 2002, 2003, 2006a, 2006b). The frequent appearance of these structures implies that the metastability of the association $G r t+Q t z$ is not related to an external cause (e.g. a sudden increase in the speed of upwelling), but rather to an internal factor related to the rock itself. The results of our Monte Carlo modeling suggest a strong tendency of Al to enrich in the $\mathrm{T}_{1}$ site. This tendency is caused by a perturbation of the charge balance on oxygen atoms connecting $\mathrm{T}_{1}$ sites due to the close proximity to $\mathrm{Mg}^{2+}$ cations. A high $\mathrm{Al}$ concentration in the $\mathrm{T}_{1}$ sites restores the balance. It is important to note that due to this intrinsic tendency the concentrations of $\mathrm{Al}$ in $\mathrm{T}_{1}$ and $\mathrm{T}_{2}$ sites in a new formed cordierite deviate from the ideal for the ordering 2/3:1/3 ratio. This decreases the chances for the nucleation of orthorhombic domains. On the contrary, the disordered hexagonal domains can form easily, however, due to the higher 
free energy of the hexagonal phase their equilibrium nucleation requires a lower pressure. The difficulty in nucleation of ordered domains could well be the cause of the delay of the growth of the orthorhombic cordierite in upwelling granulite blocks. Therefore, the commonly observed coronal and symplectite structures could be considered as an indirect evidence of the order/disorder transition.

The lower pressures of the cordierite-forming reaction (16) predicted here could well be counterbalanced with a different model of the activity of water and other gases in cordierite, which extend its stability to higher pressures (Newton, 1972). It is well known that the composition of cordierite in many mineral associations is considered as an indicator of $P, T$, and fugacities of $\mathrm{H}_{2} \mathrm{O}$ and $\mathrm{CO}_{2}$ in the metamorphic fluids (Perchuk, 2000; Harley, Carrington, 2001, Harley et al., 2002). Popov and Tomilenko (1987) using the data on granulites from the Aldan shield have shown that at high $P-T$ parameters the $\mathrm{H}_{2} \mathrm{O} / \mathrm{CO}_{2}$ distribution coefficient between cordierite and $\mathrm{H}_{2} \mathrm{O}-\mathrm{CO}_{2}$-fluid $(f l)$ is about $12,\left(X_{\mathrm{CO} 2} / X_{\mathrm{H} 2 \mathrm{O}}\right)^{f l} \approx 12\left(X_{\mathrm{CO} 2} / X_{\mathrm{H} 2 \mathrm{O}}\right)^{C r d}$, where $X_{\mathrm{CO} 2}=1$ $X_{\mathrm{H} 2 \mathrm{O}}$. This means that water is the most important component in the channels of the cordierite structure. Fig. $8 \mathrm{~b}$ shows that the effect of water activity on the location of the reactions $(17,18)$ in the $P-T$ space is opposite to the effect of the delay of in the cordierite nucleation. The further understanding of the effect of the phase transformation in cordierite on the location of the cordierite forming reactions will require a thermodynamic analysis that includes the assessment of the standard thermodynamic functions of cordierite and models of water activity in its structural channels.

\section{CONCLUSIONS}

The change in the thermodynamic properties of cordierite is investigated across the orthorhombic/hexagonal phase transition using an atomistic model. The predicted difference in the thermodynamic properties of the orthorhombic and hexagonal phases translates into a $2 \mathrm{kbar}$ difference in the pressure of cordierite-forming reactions at typical temperatures of granulite facies metamorphism. The simulations show that the $\mathrm{T}_{1}$ site in the hexagonal cordierite tends to contain more $\mathrm{Al}$ than is consistent with the $\mathrm{Al} / \mathrm{Si}$ distribution of the ordered phase. This implies the possible existence of a barrier for the equilibrium nucleation of the orthorhombic phase. We assume that the first crystallization of cordierite in the upwelling granulite blocks occurred as a metastable hexagonal phase. Since the crystallization of the hexagonal phase required lower pressures compared to those predicted for the equilibrium orthorhombic phase, the crystallization of cordierite has probably occurred with a certain delay. The rapid Al-Si ordering, which followed the nucleation of the hexagonal cordierite could make the association of quartz and garnet metastable with respect to the association of orthorhombic cordierite and orthopyroxene. The release of the chemical energy stored within the metastable association in the presence of a 
fluid phase could lead to a rapid growth of the orthorhombic cordierite and orthopyroxene over the garnet and quartz and to the formation of metasomatic coronal and symplectite structures in granulites.

Acknowledgements. The authors wish to thank V.S. Urusov for the constructive comments and for the discussion. The work was supported by the Deutsche Forschungsgemeinschaft (grant Wi-1232/14-2), the Russian Fund for the Fundamental Research (grants 05-05-64196 and 06-05-64098), the Program of the President of Russian Federation "The leading scientific schools of Russia" (grant 5338.2006.5 for L.L. Perchuk) and the Premier's Research Fellowship for J.D. Gale from the Government of Western Australia.

\section{REFERENCES}

Коржинский Д.С. Теория метасоматической зональности. Москва: Наука, 1969. 88 с. Кориковский С.П. Фации метаморфизма метапелитов. М.: Наука, 1979. 264 с.

Перчук Л.Л. Флюиды в нижней коре и верхней мантии Земли // Вестник МГУ, Сер. Геология. 2000. № 4. С. 25-36.

Перчук Л.Л. Конфигурация $P-T$ трендов как запись высокотемпературного полиметаморфизма // Докл. АН. 2005. Т. 401. № 2. С. 217-220.

Перчук Л Л., Геря Т.В., ван Ринен Д.Д. Сафонов О.Г., Смит С.А. Метаморфический комплекс Лимпопо, Южная Африка: режим декомпрессии и изобарического охлаждения гранулитов и сопряженных пород кратона Каапвааль // Петрология. 1996. № 6. С. 619648.

Перчук Л.Л., Токарев Д.А., ван Ринен Д.Д., Варламов Д.А., Геря Т.В., Сазонова Л.В., Фельдман В.И., Смит С.А., Бринк М.С., Бисшофф А.А. Динамическая и термальная история ядра взрывной структуры Вредефорт в кратоне Каапвааль, Южная Африка // Петрология. 2002. № 5. С. 451-492.

Перчук Л.Л., Сазонова Л.В., Ван Ринен Д.Д., Геря Т.В. Ультрамилониты и их значение для познания истории взрывной структуры Вредефорт, Южная Африка // Петрология. 2003. Т. 11. № 2. 128-144.

Перчук Л.Л., Варламов Д.А., Ван Ринен Д.Д. Уникальная запись Р-Т истории высокотемпературного полиметаморфизма // Докл. АН. 2006a. Т. 409. № 5. С. 968-962.

Перчук Л.Л., Геря Т.В., Ван Ринен Д.Д., Смит С.А. Р-Т тренды и проблема высокотемпературного полиметаморфизма // Петрология. 2006б. № 2. С.131-167.

Подлесский К.К. Гиперстен в ассоциации с силлиманитом и кварцем как индикатор условий метаморфизма // Докл. АН. 2003. Т. 389. № 1. С. 1-4.

Попов Н.В., Томиленко А.А.Содержание летучих компонентов в кордиеритах как индикатор флюидного режима метаморфизма //Модели эволюции процессов метаморфизма на щитах и в складчатых областях. Новосибирск, 1987. С. 14-18.

Урусов В.С., Таусон В.Л., Акимов В.В. Геохимия твердого тела. М.: ГЕОС, 1997. 500 с. Aranovich L.Ya., Podlesskii K.K. Geothermobarometry of high-grade metapelites: simultaneously operating reactions // Eds. Daly J.S., Yardley B.W.D., Cliff B.R. Evolution of Metamorphic Belts. Geological Society, London, Special Publications. 1989. V. 42. P. 41-65. 
Ashworth J.R., Chambers A.D. Symplectic reaction in olivine, the controls of intergrowth spacing in symplectites // Journal of Petrology, 2000. V. 41. P. 285-304.

Balassone, G., Franco, E., Mattia, C.A., Puliti, R. Indialite in xenolithic rocks from SommaVesuvius volcano (Southern Italy): Crystal chemistry and petrogenetic features // American Mineralogist, 2004. V. 89. P. 1-6.

Bass J.D. Elasticity of Minerals, Glasses and Melts // Ed. Ahrens Th.J. Mineral Physics and Crystallography. A Handbook of Physical Constants. American Geophys Union. AGU Reference Shelf. Ser 2. 1995. P. 45-63.

Becker U., Pollock K. Molecular simulations of interfacial and thermodynamic mixing properties of the grossular-andradite garnets // Physics and Chemistry of Minerals. 2002. V. 29. P. 52-64.

Bertram U.C., Heine V., Leslie M., Price G.D. Computer modelling of Al/Si ordering in sillimanite // Physics and Chemistry of Minerals. 1990. V. 17. P. 326-333.

Bosenick A., Dove M. T., Myers E. R., Palin E.J., Sainz-Diaz C.I., Guiton B.S., Warren M.C., Craig, M.S. Computational methods for the study of energies of cation distributions: applications to cation-ordering phase transitions and solid solutions // Mineralogical Magazine. 2001. V. 65. P. 193-219.

Bush T.S., Gale J.D., Catlow C.R.A., Battle P.D. Self-consistent interatomic potentials for the simulation of binary and ternary oxides // Journal of Material Chemistry. 1994. V. 4. P. 831-837.

Carpenter M. A., Putnis A., Navrotsky A., McConnell J.D.C. Enthalpy effects associated with $\mathrm{Al} / \mathrm{Si}$ ordering in anhydrous magnesian cordierite // Geochimica et Cosmochimica Acta. 1983. V. 47. P. 899-906.

Cho M., Fawcett J.J. Morphologies and growth mechanisms of synthetic Mg-chlorite and cordierite // American Mineralogist. 1986. V. 71, P. 78-84.

Connolly J.W.D., Williams A.R. Density-functional theory applied to phase transformations in transition-metal alloys // Physical Review. 1983. V. B27. P. 5169-5172.

Dick B.G., Overhauser A.W. Theory of dielectric constants of alkali halide crystals // Physical Review. 1958. V. 112. P. 90-103

Gale J.D. GULP - a computer program for symmetry adapted simulations of solids // Journal of Chemical Society: Faraday Transactions. 1997. V. 93. P. 629-637.

Gale J.D., Rohl A.L. The General Utility Lattice Program (GULP) // Molecular Simulations. 2003. V. 29. P. 291-341.

Gerya T.V., Perchuk L.L., Van Reenen D.D., Smit C.A. Two-dimensional numerical modeling of pressure-temperature-time paths for the exhumation of some granulite facies terrains in the Precambrian // Journal of Geodynamics. 2000. V. 30. P. 17-35.

Harley S.L. The origins of granulites: a metamorphic perspective // Geological Magazine. 1989. V. 126. P. 215-247.

Harley S.L., Carrington D.P. The distribution of $\mathrm{H}_{2} \mathrm{O}$ between cordierite and granitic melt: $\mathrm{H}_{2} \mathrm{O}$ incorporation in cordierite and its application to high-grade metamorphism and crustal anatexis // Journal of Petrology. 2001. V. 42. P. 1595-1620.

Harley S.L., Thompson P., Hensen B.J., Buick I.S. Cordierite as a sensor of fluid conditions in high-grade metamorphism and crustal anatexis // Journal of Metamorphic Geology. 2002. V. 20. P. 71-86.

Kitamura M., Hiroi, Y. Indialite from Unazuki politic schist, Japan, and its transition texture to cordierite // Contributions to Mineralogy and Petrology. 1982. V. 80. P. 110-116.

Kitamura M., Yamada H. Origin of sector trilling in cordierite in Daimonji hornfels, Kyoto, Japan // Contributions to Mineralogy and Petrology. 1987. V. 97. P. 1-6. 
Langer K., Schreyer $W$. Infrared and powder X-ray diffraction studies of the polymorphism of cordierite // American Mineralogist. 1969. V. 54. P. 1442-1459.

Lewis G.V., Catlow C.R.A. Potential models for ionic oxides // Journal of Physics. Ser. C: Solid State Physics. 1985. V. 18, P. 1149-1161.

Malcherek T., Domeneghetti M.C., Tazzoli V., Ottolini L., McCammon C.A., Carpenter M.A. Structural properties of ferromagnesian cordierites // American Mineralogist. 2001. V. 86. P. 6679 .

Metropolis N.I., Rosenbluth A.W., Rosenbluth M.N., Teller A.N., Teller E. Equation of state calculations by fast computing machines // Journal of Chemical Physics. 1953. V. 21.

P. 1087-1092.

Myers E.R., Heine V., Dove M.T. Some consequences of Al/Al avoidance in the ordering of $\mathrm{Al} / \mathrm{Si}$ tetrahedral framework structures // Physics and Chemistry of Minerals. 1998. V. 25. P. 457-464.

Newton R.C. An experimental determination of the high-pressure stability limits of magnesian cordierite under wet and dry conditions // Journal of Geology. 1972. V. 80. P. 398-420.

Patel A., Price G.D., Mendelsson M.J. A computer-simulation approach to modeling the structure, thermodynamics and oxygen isotope equilibria of silicates // Physics and Chemistry of Minerals. 1991. V. 17. P. 690-699.

Perchuk L.L. Thermodynamic control of metamorphic processes // Energetics of Geological Processes. Eds. S.K. Saxena, S.Bhattacharji. N.Y.: Springer Verlag, 1977. P. 285-352.

Perchuk L.L. P-T-fluid regimes of metamorphism and related magmatism with specific reference to the Baikal Lake granulites. // Evolution of Metamorphic belts. Eds. S. Daly, D.W.D. Yardley, B. Cliff. Geological Society of London: Special Publication. 1989. V. 2. № 20. P. 275-291.

Perchuk L.L. Lavrent'eva I.V. Experimental investigation of exchange equilibria in the system cordierite-garnet-biotite // Advances in Physical Geochemistry. New York: Springer Verlag, 1983. P. 199-239.

Perchuk L.L., Gerya T.V., van Reenen D.D., Smit C.A. Formation, dynamics of granulite complexes within cratons // Gondwana Research. 2001. V. 4. № 4. P. 729-732.

Putnis A. Introduction to mineral sciences. Cambridge: Cambridge University Press, 1992. 457 p.

Putnis A., Holland T. J.B. Sector trilling in cordierite, equilibrium overstepping in metamorphism // Contributions to Mineralogy and Petrology, 1986. V. 9. P. 265-272.

Putnis A., Vinograd V. L. Principles of solid state NMR spectroscopy, applications to determining local order in minerals // Eds. K. Wright, R. Catlow Microscopic Properties and Processes in Minerals. NATO Science Series C. 1999. V. 543. P. 389-425.

Putnis A., Fyfe C.A., Gobbi G.C. Al,Si ordering in cordierite using "Magic angle spinning" NMR I. ${ }^{29} \mathrm{Si}$ Spectra of synthetic cordierites // Physics and Chemistry of Minerals. 1985. V. 12. P. 211216.

Putnis A., Salje E., Redfern S.A.T., Fyfe C., Stroble H. Structural states of Mg-cordierite I: Order parameters from synchrotron X-ray and NMR data // Physics and Chemistry of Minerals. 1987. V. 14. P. 446-456.

Sanchez J.M., Ducastelle F., Gratias D. Generalized cluster description of multicomponent systems // Physica. 1984. V. 128A. P. 334-350.

Schreyer W., Schairer, J.F. Compositions and structural states of anhydrous Mg-cordierites: a reinvestigation of the central part of the system $\mathrm{MgO}-\mathrm{Al}_{2} \mathrm{O}_{3}-\mathrm{SiO}_{2} / /$ Journal of Petrology. 1961. V. 2. P. 324-406. 
Schreyer W., Yoder H. S. The system Mg-cordierite- $\mathrm{H}_{2} \mathrm{O}$ and related rocks // Noues Yharbuch Mineralogische Abhandlungen. 1964. V. 101. P. 271-342.

Skippen G.B., Gunter A.E. The thermodynamic properties of $\mathrm{H}_{2} \mathrm{O}$ in magnesium and iron cordierite // Contributions to Mineralogy and Petrology. 1996. V. 124. P. 82-89.

Smart R.M., Glasser F.P. Stable cordierite solid solutions in the $\mathrm{MgO}-\mathrm{Al}_{2} \mathrm{O}_{3}-\mathrm{SiO}_{2}$ system: Composition, polymorphism and thermal expansion // Science of Ceramics. 1977. V. 9. P. 256263.

Smit, C.A., Van Reenen, D.D., Gerya, T.V., Perchuk, L.L. P-T conditions of decompression of the Limpopo high-grade terrain: record from shear zones // Journal of Metamorphic Geology. 2001. V. 19. P. 249-268.

Spear F.S. Metamorphic phase equilibria and pressure-temperature-time paths. Washington. Mineralogical Society of America Publication. 1993. 799 p.

Thayaparam S., Heine V., Dove M. T., Hammonds K. T. A computational study of Al/Si ordering in cordierite // Physics and Chemistry of Minerals. 1996. V. 23. P. 127-139.

Toohill K., Siegesmund S., Bass J.D. Sound velocities, elasticity of cordierite and implications for deep crustal seismic anisotropy // Physics and Chemistry of Minerals. 1999. V. 26. P. 333343.

Torres F.J., Alarcon J. Phase evolution by thermal treatment of equimolar cobalt-magnesium cordierite glass powders // Journal of the European Ceramic Society. 2004. V. 4. P. 681-691.

Van Reenen D.D., Perchuk L.L., Smit C.A., Boshoff R., Varlamov, D.A., Huizenga, J.M., Gerya, T.V. Structural and P-T evolution of a major cross fold in the Central Zone of the Limpopo high-grade terrain, South Africa // Journal of Petrology. 2004. V. 45. P. 1413 - 1439.

Vielzeuf, D., Vidal, Ph. (Eds.) Granulites and Crustal Evolution. NATO ASI Series. Series C. Kluwer, Dordrecht. 1990. V. 311. P. 257-289.

Vinograd V.L., Sluiter M.H.F., Winkler B., Putnis A., Gale J.D. Thermodynamics of mixing, ordering in silicates, oxides from static lattice energy, ab initio calculations // Eds. Warren M., Oganov A., Winkler B. First-Principles Simulations: Perspectives and Challenges in Mineral Sciences (Deutsche Gesellschaft für Kristallographie. Berichte aus Arbeitskreisen der DFK 14). 2004. P. 143-151.

Vinograd V.L., Winkler B., Putnis A., Kroll H., Milman V., Gale J.D., Fabrichnaya O.B. Thermodynamics of pyrope - majorite, $\mathrm{Mg}_{3} \mathrm{Al}_{2} \mathrm{Si}_{3} \mathrm{O}_{12}-\mathrm{Mg}_{4} \mathrm{Si}_{4} \mathrm{O}_{12}$, solid solution from atomistic model calculations // Molecular Simulations. 2006. V. 32. № 2. P. 86-99.

Warren M.C., Dove M.T., Myers E.R., Bosenick A., Palin E.J., Sainz-Diaz C.I., Guiton B.S. Monte Carlo methods for the study of cation ordering in minerals // Mineralogical Magazine. 2001. V. 65. P. 221-24.

Winkler B., Dove M.T., Leslie M. Static lattice energy minimization and lattice dynamics calculations on aluminosilicate minerals // American Mineralogist. 1991. V. 76. P. 313-331. 
Table 1. The interatomic potentials used in this study.

\begin{tabular}{|c|c|c|c|c|}
\hline $\begin{array}{c}\text { Buckingham } \\
\text { potential }\end{array}$ & \multicolumn{2}{|c|}{$A, \mathrm{eV}$} & $\rho, \AA$ & $C, \mathrm{eV}^{*} \AA^{6}$ \\
\hline $\mathrm{Al}$ (core)-O(shell) & \multicolumn{2}{|c|}{1115.68660} & 0.291905 & 0.0 \\
\hline $\mathrm{Mg}($ core $)-\mathrm{O}($ shell $)$ & \multicolumn{2}{|c|}{1190.52540} & 0.284037 & 0.0 \\
\hline Si(core)-O(shell) & \multicolumn{2}{|c|}{995.922380} & 0.304057 & 0.0 \\
\hline $\mathrm{O}($ shell $)-\mathrm{O}($ shell $)$ & \multicolumn{2}{|c|}{593.055530} & 0.321826 & 29.61488 \\
\hline Spring potential & \multicolumn{3}{|c|}{$k_{\mathrm{S}}, \mathrm{eV}^{*} \AA^{-2}$} & \\
\hline $\mathrm{O}($ core $)-\mathrm{O}($ shell $)$ & \multicolumn{3}{|c|}{56.663970} & \\
\hline \multicolumn{2}{|l|}{ Three-body potential } & \multicolumn{2}{|c|}{$k_{\theta}\left(\mathrm{eV}^{*} \mathrm{rad}^{-2}\right)$} & $\theta$ (degree) \\
\hline \multicolumn{2}{|c|}{ O(shell)-Si[4]- O(shell) } & \multicolumn{2}{|c|}{2.5171} & 109.47 \\
\hline \multicolumn{2}{|c|}{ O(shell)-Si[6]- O(shell) } & \multicolumn{2}{|l|}{2.9253} & 90.0 \\
\hline \multicolumn{2}{|c|}{$\mathrm{O}$ (shell)-Al[4]- O(shell) } & \multicolumn{2}{|c|}{1.0372} & 109.47 \\
\hline \multicolumn{2}{|c|}{ O(shell)-Al[6]- O(shell) } & \multicolumn{2}{|c|}{1.4693} & 90.0 \\
\hline \multicolumn{2}{|c|}{$\mathrm{O}($ shell$)-\mathrm{Mg}[6]-\mathrm{O}($ shell $)$} & \multicolumn{2}{|c|}{1.0514} & 90.0 \\
\hline
\end{tabular}

Note. The charges of the core and shell are 0.751575 and $-2.451575 e$, respectively. The cutoff distance of the Buckingham potential is $12 \AA$.

Table 2. The unit cell parameters and the elastic stiffness constants of cordierite.

\begin{tabular}{lll}
\hline Parameters & Experiment & Calculation \\
\hline Volume, $\AA^{3}$ & $1552.824^{\mathrm{a}}$ & 1551.740 \\
$a, \AA$ & $17.081^{\mathrm{a}}$ & 17.098 \\
$b, \AA$ & $9.731^{\mathrm{a}}$ & 9.728 \\
$c, \AA$ & $9.343^{\mathrm{a}}$ & 9.329 \\
$K$ & $129^{\sigma}$ & 125.4 \\
$G$ & $54^{\sigma}$ & 54.2 \\
$C_{11}$ & $213.6^{\sigma}$ & 209.04 \\
$C_{12}$ & $93.7^{\sigma}$ & 93.88 \\
$C_{13}$ & $88.9^{\sigma}$ & 84.05 \\
$C_{22}$ & $207.3^{\sigma}$ & 201.52 \\
$C_{23}$ & $95.1^{\sigma}$ & 84.98 \\
$C_{33}$ & $186.1^{\sigma}$ & 194.54 \\
$C_{44}$ & $51.6^{\sigma}$ & 50.88 \\
$C_{55}$ & $46.5^{\sigma}$ & 45.95 \\
$C_{66}$ & $64.0^{\sigma}$ & 63.95 \\
\hline
\end{tabular}

Note. The experimental data: (a) Malchereck et al., 2001 (the sample from Zimbabve);

(b) Toohill et al., 1999. $K$ and $G$ are the bulk and sheer modulii (GPa). $C_{\mathrm{ij}}$ are the elastic stiffness constants (GPa). 
Table 3. The pair interaction energies at different interatomic distances.

\begin{tabular}{|c|c|c|c|}
\hline$n$ & Distance, $\AA$ & $\begin{array}{l}\text { Type of } \\
\text { the pair }\end{array}$ & $\begin{array}{l}\text { Energy, } \\
\mathrm{kJ} / \mathrm{mol}\end{array}$ \\
\hline 1 & 3.062 & 12 & -52.7717 \\
\hline 2 & 3.246 & 22 & -79.6716 \\
\hline 3 & 3.961 & 22 & -26.9871 \\
\hline 4 & 4.124 & 12 & -28.5033 \\
\hline 5 & 4.519 & 22 & -23.0664 \\
\hline 6 & 4.670 & 11 & -24.1588 \\
\hline 7 & 4.884 & 11 & -14.0174 \\
\hline 8 & 4.925 & 22 & -15.309 \\
\hline 9 & 5.004 & 22 & -12.8255 \\
\hline 10 & 5.622 & 22 & -10.1828 \\
\hline 11 & 5.675 & 12 & -14.7967 \\
\hline 12 & 5.855 & 12 & -12.8005 \\
\hline 13 & 5.855 & 22 & -34.3266 \\
\hline 14 & 6.488 & 22 & -1.30007 \\
\hline 15 & 6.492 & 22 & 6.14937 \\
\hline 16 & 6.608 & 22 & -0.639798 \\
\hline 17 & 6.710 & 22 & -9.89917 \\
\hline 18 & 6.758 & 11 & -9.80573 \\
\hline 19 & 6.799 & 22 & -13.0977 \\
\hline 20 & 6.890 & 12 & -3.36312 \\
\hline 21 & 6.910 & 22 & -8.69881 \\
\hline 22 & 7.032 & 12 & -6.78555 \\
\hline 23 & 7.094 & 22 & -13.3681 \\
\hline 24 & 7.129 & 22 & -3.01528 \\
\hline 25 & 7.280 & 12 & -13.3669 \\
\hline 26 & 7.765 & 22 & -4.67145 \\
\hline 27 & 7.787 & 12 & -2.13392 \\
\hline 28 & 7.793 & 22 & 0.219364 \\
\hline 29 & 7.830 & 22 & -7.0762 \\
\hline 30 & 7.843 & 22 & -0.662114 \\
\hline
\end{tabular}

Note. The pairs 11, 22 and 12 correspond to M1-M1, M2-M2 and M1-M2 contacts, respectively.

Table 4. The peak intensitities of ${ }^{29} \mathrm{Si}$ NMR-spectra according to the experiment and model calculations. (E - Experiment, MC - Monte Carlo)

\begin{tabular}{cccccc|ccccc}
\hline \multirow{2}{*}{$T, \mathrm{~K}$} & \multicolumn{5}{c|}{$\mathrm{T}_{1}$ site } & \multicolumn{5}{c}{$\mathrm{T}_{2}$ site } \\
\cline { 2 - 10 } & $\mathrm{Si}(0 \mathrm{Al})$ & $\mathrm{Si}(1 \mathrm{Al})$ & $\mathrm{Si}(2 \mathrm{Al})$ & $\mathrm{Si}(3 \mathrm{Al})$ & $\mathrm{Si}(4 \mathrm{Al})$ & $\mathrm{Si}(0 \mathrm{Al})$ & $\mathrm{Si}(1 \mathrm{Al})$ & $\mathrm{Si}(2 \mathrm{Al})$ & $\mathrm{Si}(3 \mathrm{Al})$ & $\mathrm{Si}(4 \mathrm{Al})$ \\
\hline $1673 \mathrm{E}$ & 0.0000 & 0.0163 & 0.0437 & 0.0510 & 0.0524 & 0.0000 & 0.0446 & 0.2653 & 0.4371 & 0.0892 \\
$1573 \mathrm{MC}$ & 0.0025 & 0.0109 & 0.0287 & 0.0642 & 0.0600 & 0.0068 & 0.0455 & 0.2020 & 0.5406 & 0.0388 \\
$1623 \mathrm{MC}$ & 0.0032 & 0.0207 & 0.0502 & 0.0495 & 0.0214 & 0.0055 & 0.0594 & 0.3144 & 0.4277 & 0.0482 \\
$1673 \mathrm{MC}$ & 0.0036 & 0.0233 & 0.0532 & 0.0464 & 0.0167 & 0.0053 & 0.0624 & 0.3292 & 0.4100 & 0.0498 \\
\hline
\end{tabular}


Figure captions

Fig. 1. The enthalpy of disorder in dry Mg-cordierite calculated using the Monte Carlo method.

Fig. 2. The average Al-occupancies in $T_{1}$ and $T_{2}$ sites of cordierite according to results of the Monte Carlo simulations.

Fig. 3. The Gibbs free energies of the hexagonal and orthorhombic phases. The open circles correspond to equilibrium free energy calculated via the thermodynamic integration of Monte Carlo results. The filled circles correspond to non-equilibrated disordered cordierite.

Fig. 4. The configurational entropy of cordierite calculated via the thermodynamic integration of Monte Carlo results.

Fig. 5. The temperature dependence of the parameters of long-range order calculated for $T_{1}$ and $\mathrm{T}_{2}$ sites in cordierite from the results of Monte Carlo simulations.

Fig. 6. The probability of Al-Al contacts for the nearest-neighbour tetrahedral sites in cordierite.

Fig. 7. The temperature dependence of short-range order parameters for $T_{1}-T_{2}$ and $T_{2}-T_{2}$ pairs of cordierite calculated from the results of Monte Carlo simulations.

Fig. 8. Some of the cordierite-producing reactions in granulite facies metapelites. (a) The isopleths of constant mineral composition of cordierite and indialite (the solid and dashed lines, respectively) which correspond to the reaction (16) at $a\left(\mathrm{H}_{2} \mathrm{O}\right)=0.2$. The mineral compositions, the standard thermodynamic functions and the models of mixing are from Smit et al., (2001). The box in Fig. 8 a shows schematically the change in the slope of the isopleths due to the order/disorder transition. (b) The stability limits of the orthorhombic dry $\left(C r d_{(d r y y}\right)$ and wet $\left(\mathrm{Crd}_{\text {(velt) }}\right) \mathrm{Mg}$-cordierite in $\mathrm{P}-\mathrm{T}$ coordinates calculated using the thermodynamic data of Podlessky (2003), Holland and Powell (1998) and Spear (1993). (c) - The reaction texture of Opx $+\mathrm{Crd}$ developed over the association of garnet and quartz according to the reaction (17) in a metapelite from the granulite terrain Limpopo, South Africa (Perchuk et al., 2006b). (d) The reaction texture of $\mathrm{Spr}+\mathrm{Crd}$ developed over the association of orthopyroxene and sillimanite according the reaction (19) in a metapelite from Sutam Complex of the Aldan shield (Photo by S.P. Korikovski, see also Vielzeuf and Vidal, 1990). The images $c$ and $d$ are in polarized light. It is assumed (see Gerya et al., 2000) that all the zones have been grown simultaneously consistently with the theory of Korzhinsky (1969) at continuously decreasing $P$ and $T$ parameters.

Fig. 9. The reactions (17) and (18) completed with the formation of $\mathrm{Crd}+\mathrm{Opx}(\mathrm{a})$ and $\mathrm{Crd}$ $(+Q t z)(b)$ pseudomorphs over garnet. The image $a$ is in back-scattered electrones (Perchuk et al., 1996). The image $b$ is in polarized light (van Reenen et al., 2004). 


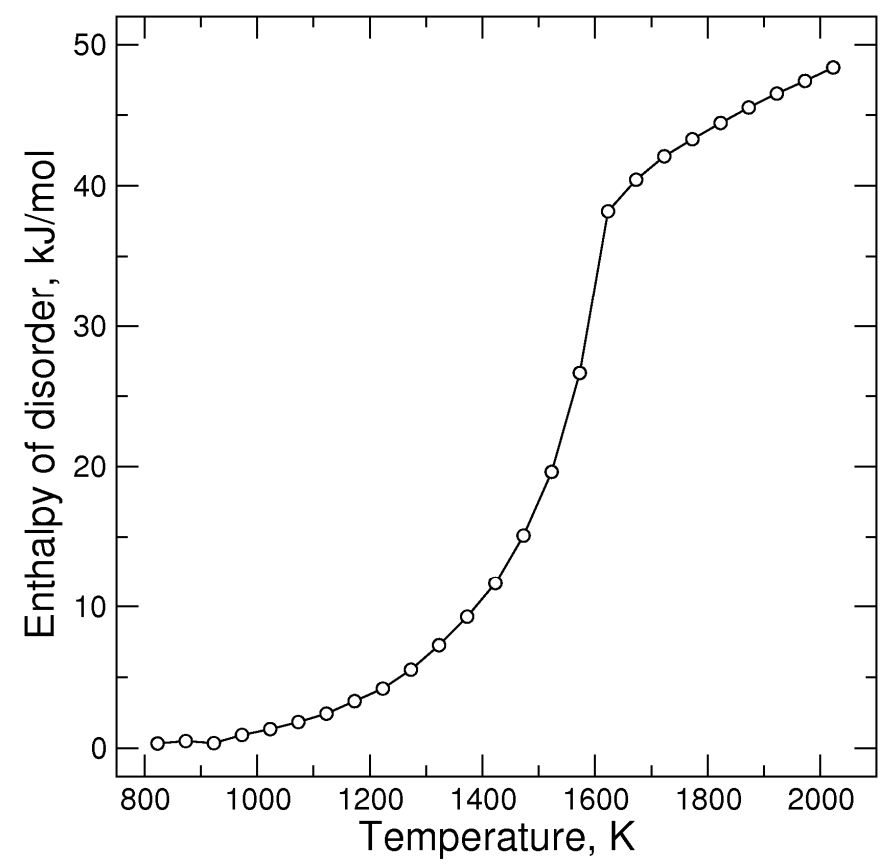

Fig. 1

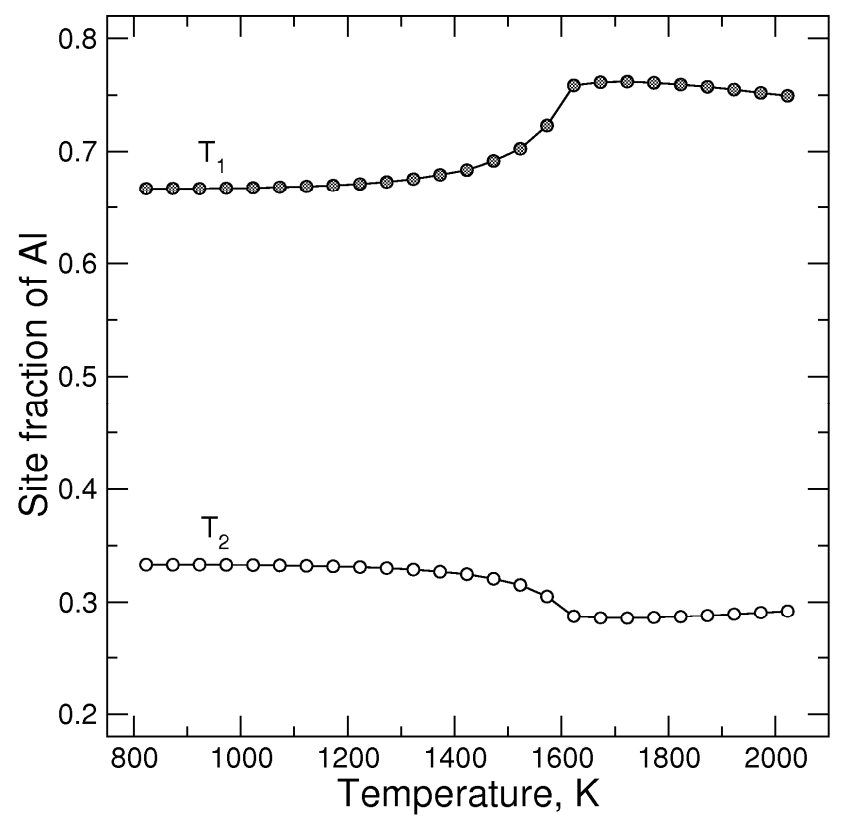

Fig. 2 


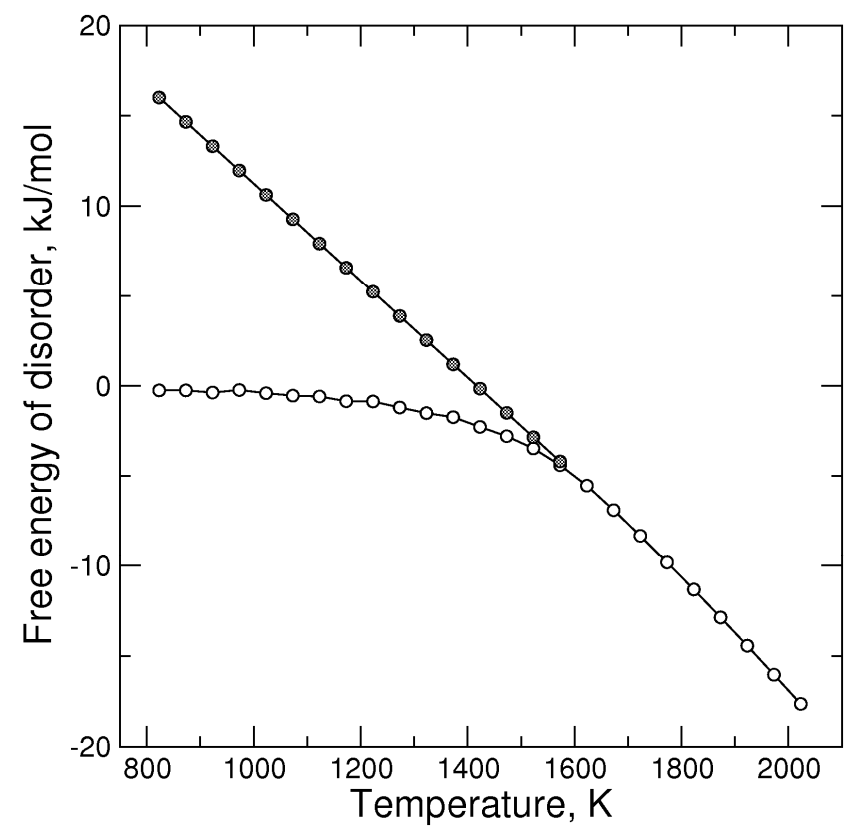

Fig. 3.

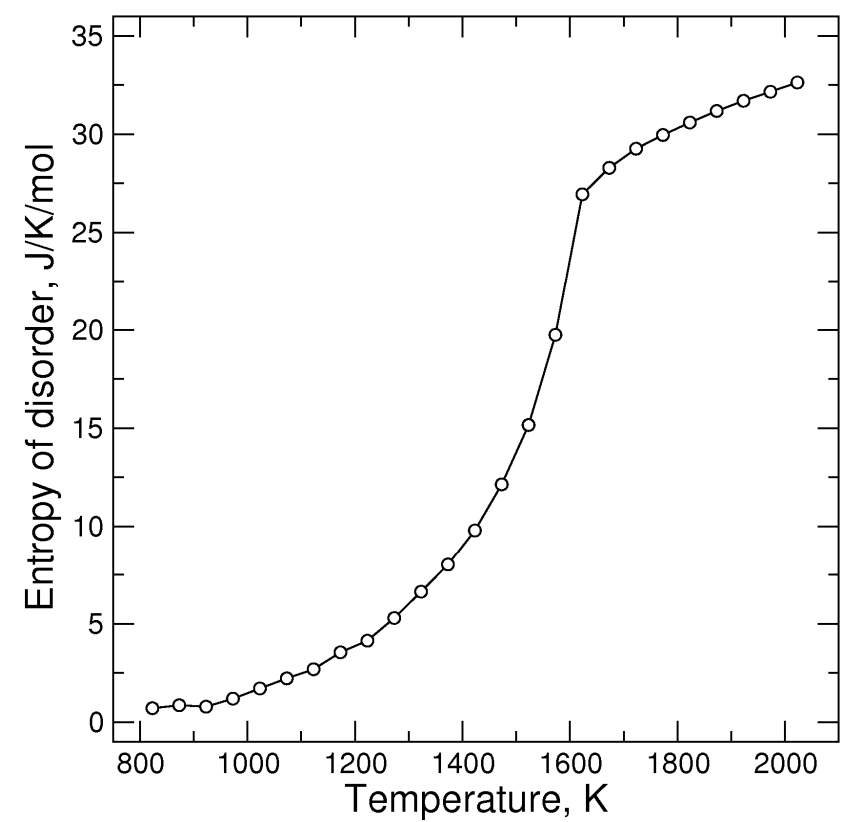

Fig. 4. 


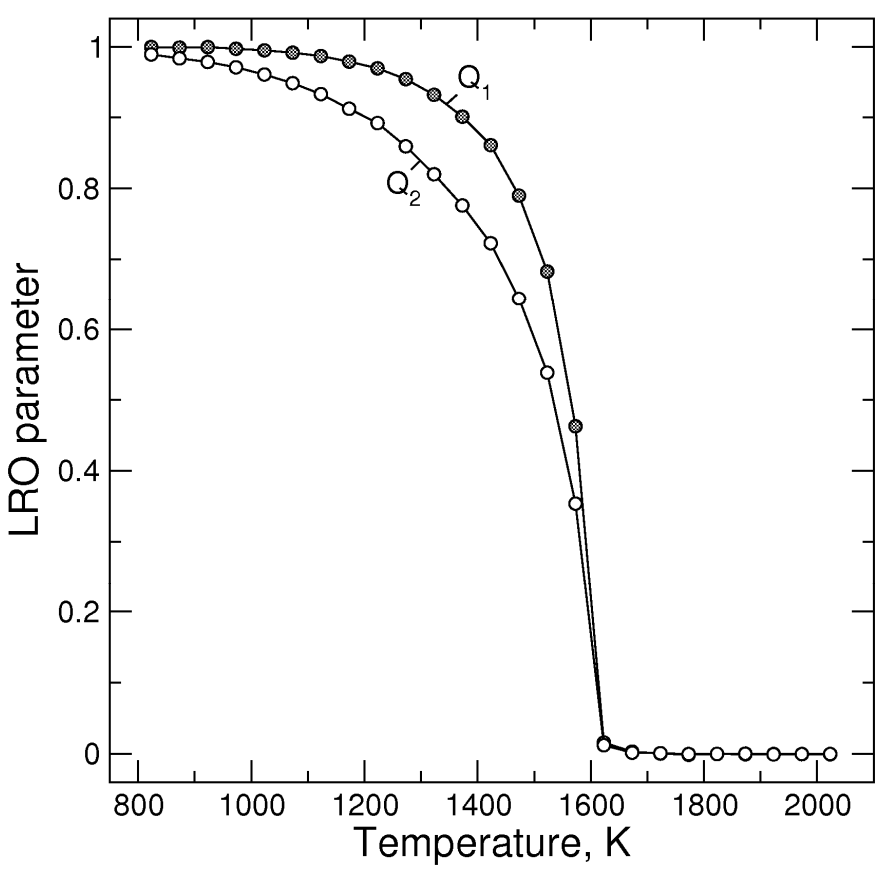

Fig. 5.

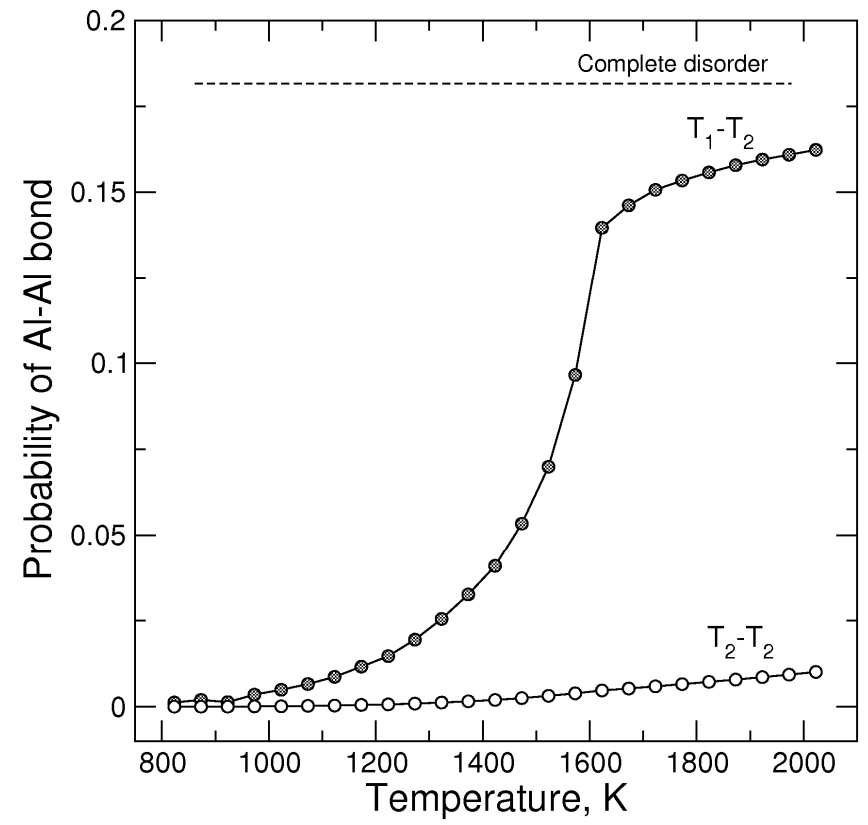

Fig. 6. 


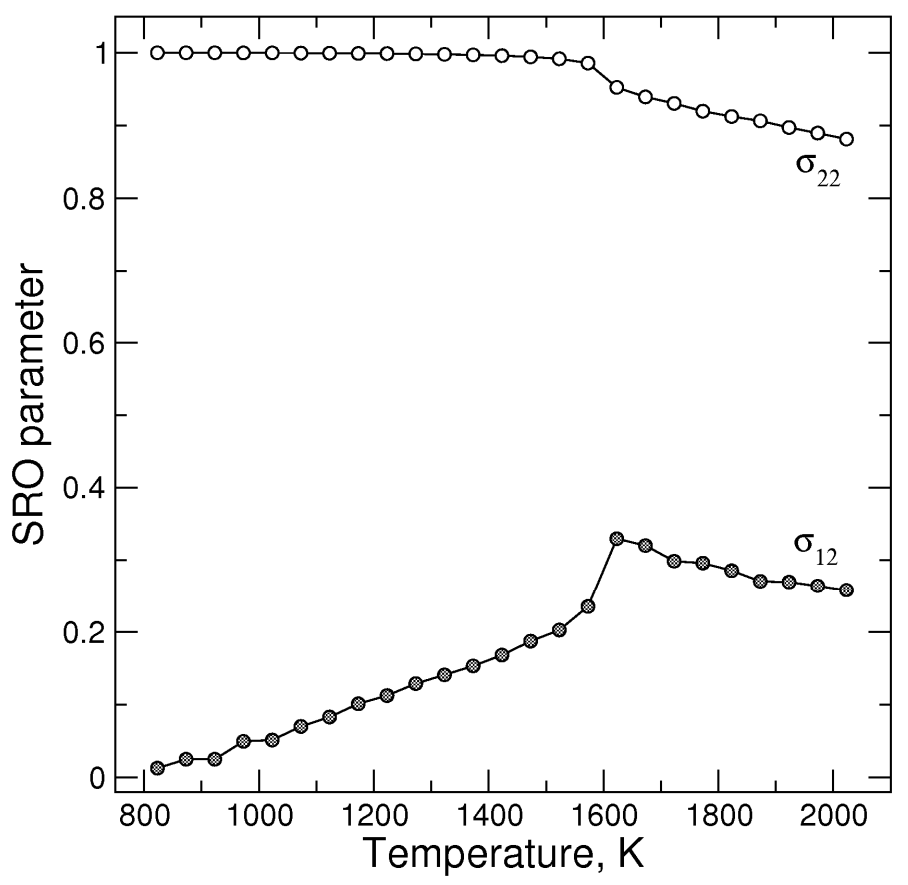

Fig. 7.

a

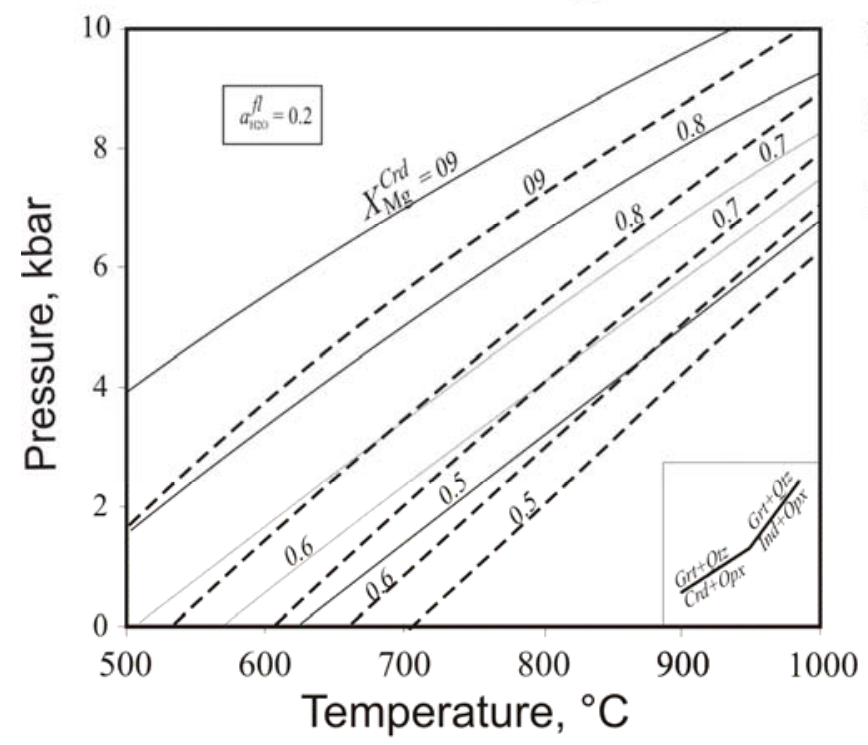

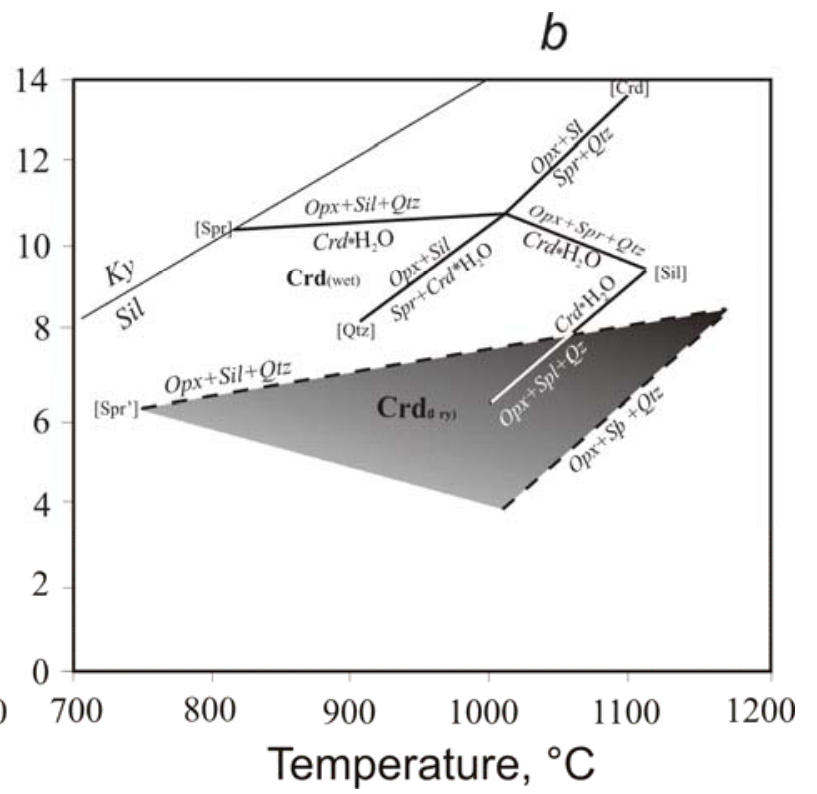




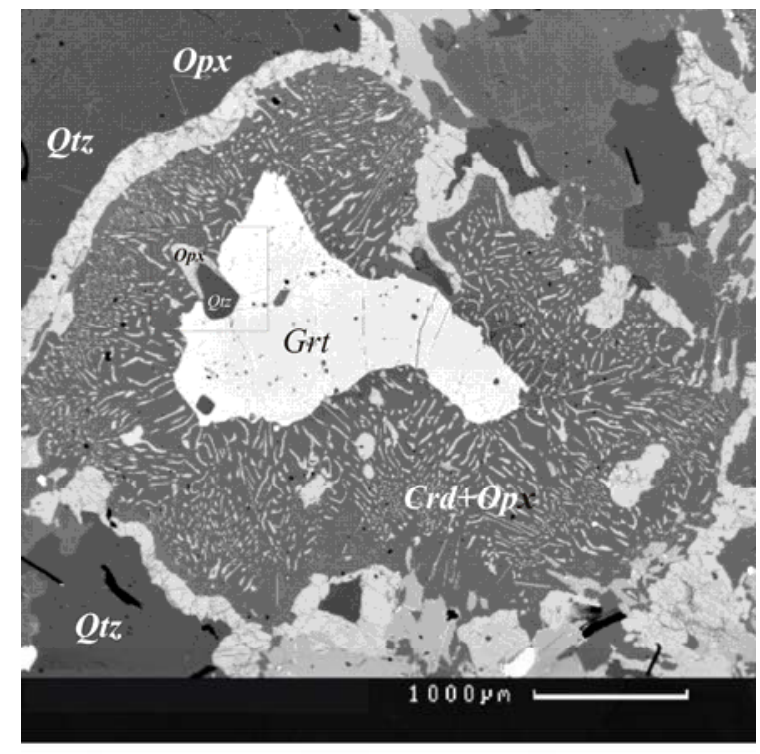

Fig.8c

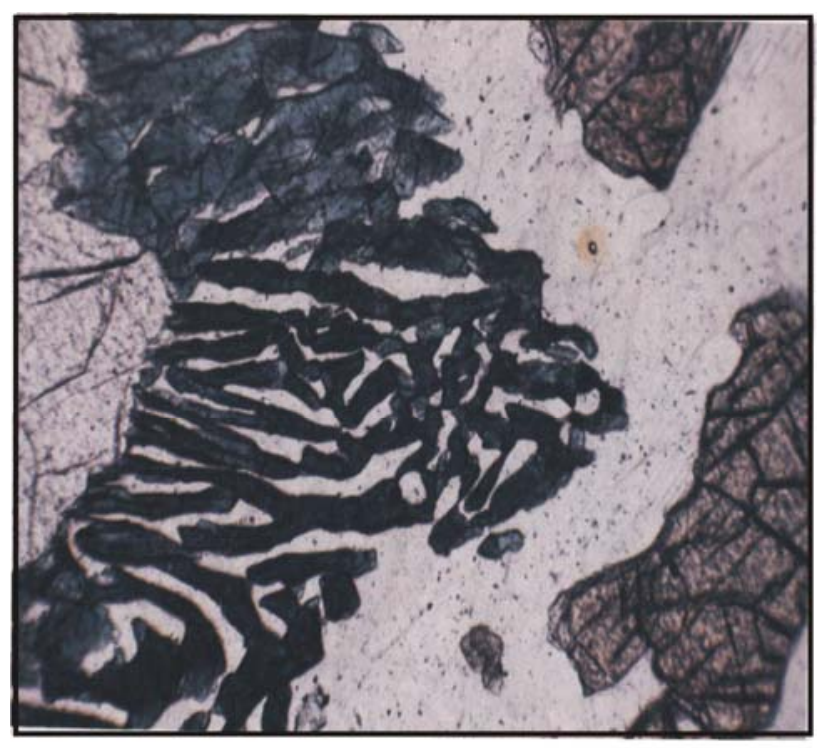

Fig.8d

Fig. 8.

a

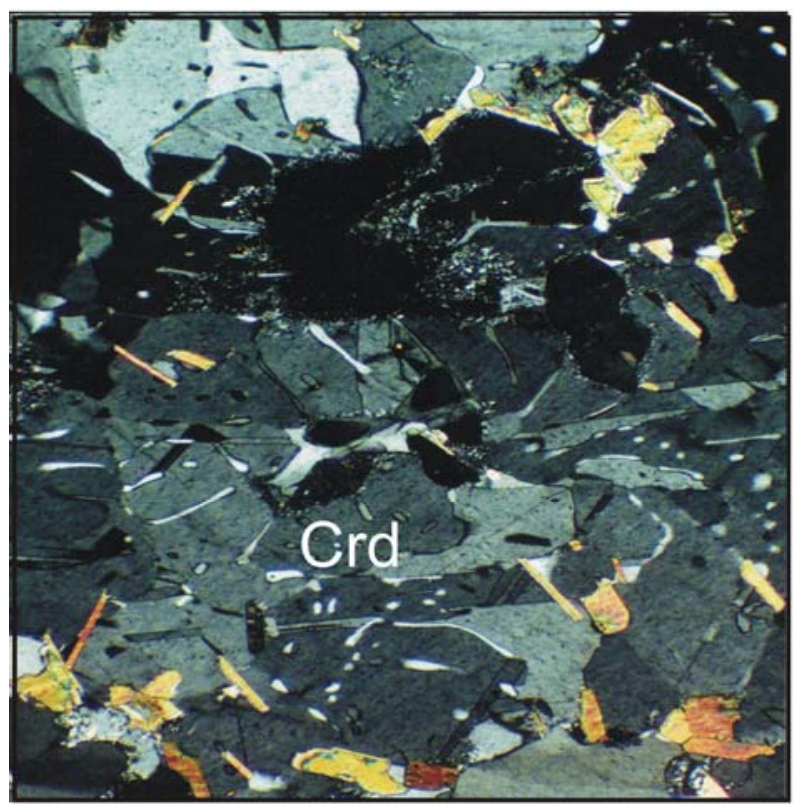

Fig. 9. b

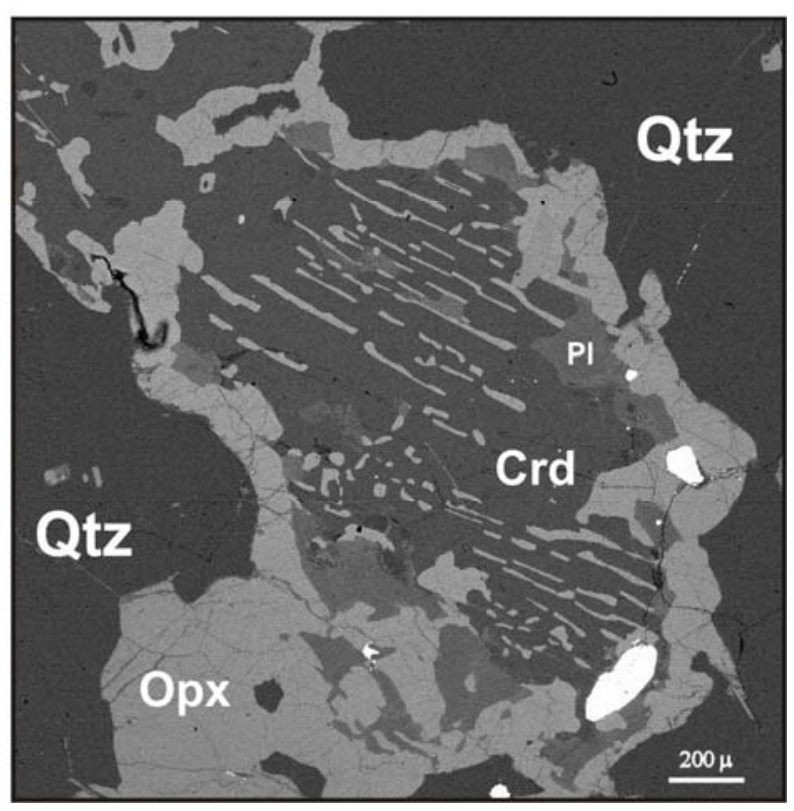

